IHR

32,1

8

Received 5 July 2018 Revised 8 September 2018 Accepted 9 September 2018

\section{The restauranteurship of Hong Kong's premium Japanese restaurant market}

\author{
Watson Baldwin \\ Faculty of Management and Hospitality, \\ Technological and Higher Education Institute of Hong Kong, Hong Kong
}

\begin{abstract}
Purpose - Hong Kong has a global reputation as an entrepreneurial hub. The Japanese restaurant community has grown and evolved over the last three decades into what many consider as a natural secondary market for Japanese food. As such, several Japanese restaurateurs have come to Hong Kong to enter Hong Kong's premium Japanese restaurant market. The purpose of this paper is to explore this market of Japanese restauranteurship in Hong Kong.

Design/methodology/approach - One of the closest methodologies within the topic and discipline from Baldwin (2017) focuses on Japaneseness as a measurement of culinary authenticity examining Hong Kong's Michelin rated restaurants. Here, the qualitative approach using semi-structured interviews with the chefs of two sets of premium Japanese restaurants from Japan that expanded in Hong Kong, Sushi Iwa and Sushi Yoshitake. As this paper focuses on the premium and high-end market of Japanese chefs and restaurateurs in Hong Kong, the researcher combined the approaches of Kawahara \& Speece and Baldwin to pursue a qualitative methodology using semi-structured interviews.

Findings - For this research, the interview process had to be divided into two stages. The first was to speak with long standing members of Hong Kong's Japanese restaurant community. The common thread amongst the restaurateurs was that they were either the sole proprietor or a partner who was financially vested within the company not a form of sweat equity. To respect the privacy of the interviews, questions about exact monetary amounts, number of shares and equity or anything regarding holdings were not asked. The idea was to only examine their responses within the criteria of the research objectives.

Research limitations/implications - As the Michelin and premium market of Japanese cuisine is so small, this research can only represent a certain part of the market. Future research could examine other Japanese restaurateurs outside of this market that could be examined to gain a wider perspective of the entrepreneurial strategies they used to start-up their business in Hong Kong.

Originality/value - As research in this area is very limited, this paper helps bring restauranteurship in Hong Kong into the academic front. Restaurants are one of the most common entry points for new entrepreneurs in hospitality. This paper may help shed some light on how foreign investment entrepreneurship has been achieved in Asia.
\end{abstract}

Keywords Hong Kong, Entrepreneurship, Japanese restaurants, Michelin, Restauranteurship

Paper type Case study

\section{Introduction}

Hong Kong is currently one of the world's most dynamic restaurant landscapes that is fused with rich history and modern innovations of cuisine (Baldwin, 2017; Lee, 2009). Boasting over 10,000 food and beverage outlets, Hong Kong is making its mark as a culinary haven (Hong Kong Industrial Classification, 2018; HKTB, 2018). The free port city has long been renowned for its unique blend of eastern and western culinary culture, which in turn has spawned an interesting entrepreneurial restaurant environment. Post British occupation, Hong Kong has evolved from fishing and farming to become a center point for finance, trade

(c) Watson Baldwin. Published in International Hospitality Review. Published by Emerald Publishing Limited. This article is published under the Creative Commons Attribution (CC BY 4.0) licence. Anyone may reproduce, distribute, translate and create derivative works of this article (for both commercial and non-commercial purposes), subject to full attribution to the original publication and authors. The full terms of this licence may be seen at http://creativecommons.org/licences/by/4.0/legalcode
International Hospitality Review Vol. 32 No. 1, 2018 pp. 8-25

Emerald Publishing Limited 2516-8142 DOI 10.1108/IHR-07-2018-0004 
and internationalization for the region (Cheung and Zou, 2013; Baldwin, 2017). Hong Kong has shown itself to be a critical point of entry for large restaurant corporations and small-to-medium enterprises (SME) for the region and specifically China. This can be seen very well within the Japanese restaurant market of Hong Kong, particularly of the premium and upscale Japanese restaurants within the city. Japanese cuisine and the subsequent restaurants have played a major role in the evolution of Hong Kong's global culinary status as well the culinary culture of Hong Kong. Japanese chefs and restaurateurs are a leading force within the restaurant community (Baldwin, 2017).

This paper seeks to explore the challenges that chefs and restaurateurs of Hong Kong's Japanese restaurants have used to break into the market.

\section{Problem statement}

Entrepreneurship is a very hot topic for both academic research and industry application. Within the academic realm, entrepreneurship is well discussed and presented across a variety of industries. Most commonly, the technology sector is the first thought for most that have examined entrepreneurship. As for research within the restaurant aspect of academic research and entrepreneurship, there is a smaller scope particularly for Hong Kong. At present, the Asian wave of hospitality is taking center stage, with restaurants playing a vital role in the region's progression (Chen and Chon, 2016). Wan and Chon (2010) identified the concept of the Asian paradigm of hospitality in that the world was transitioning to a more Asia focused perspective of hospitality. The Japanese and their cuisine are a part of this forefront (JETRO, 2017; InvestHK, 2018). With Hong Kong being Asia's Culinary Capital, the Japanese have found this market good transition stage outside their native market. Previous research has not examined Hong Kong's entrepreneurial standing from a perspective of restaurants, Japanese cuisine or Japanese restaurateurs. From the Japanese side, there is a research that examines entrepreneurship in Japan focused on the migrant population and their motivations by Rahman and Rahman (2012); entrepreneurship within academic institutions focused on science and technology as put forth by Shi and Yonezawa (2012); as well as large-scale aspect of Japanese supermarkets in Hong Kong by Kawahara and Speece (1994) and Nakano (2015). These leaves a very large gap for research specifically focused on Japanese restauranteurship in Hong Kong.

The questions that this research intends to answer are as follows:

$R Q 1$. What factors led Japanese restaurateurs to open their business in Hong Kong?

RQ2. What are the barriers to entry for Japanese restaurateurs within Hong Kong's restaurant market?

\section{Literature review}

\section{Entrepreneurship}

Having first been introduced as a concept by Richard Cantillion (1755) from his writings discussing economic theory, entrepreneurship has been heavily debated within the academic community. Scholars argue as to what defines an entrepreneur, i.e. the creation of new firms (Lee and Peterson, 2000), degrees of innovation affecting value and growth (McDougall and Oviatt, 1997) and individuals pursing new business opportunities within a particular market (Brush et al., 2003; Busenitz et al., 2003; Stevenson and Jarillo, 1990). Soriano and Montoro-Sanchez (2018) describe entrepreneurship as the capability to react and anticipate to market conditions thus capitalizing on an opportunity to provide goods and services at an economical value. This is also in line with Eckhardt and Shane's (2003) definition of obtaining the resources and development a strategy to support and grow a new business project. 
IHR

32,1

Current entrepreneurship research has been contextualized under different aspects of the economic discipline (Welter, 2011). Gartner (1995) goes on to say that, as observers of the entrepreneurial process, scholars have underestimated the multitude of external factors and overestimated the influences of internal factors that contribute to entrepreneurial success. The previous aspects of context: social, spatial, institutional and societal have strong merit within the study of the discipline but there are often dramatic shifts in the perceived rules of entrepreneurship (Baumol, 1990; Low and MacMillan, 1988; Granovetter, 1985; Katz and Steyaert, 2004; Polanyi, 1957; Weber; 1984). Concerning entrepreneurship in today's global environment, the dramatic shift in rules is still present. In today's environment, there is growth for SMEs in different regions around the world, Hong Kong being one them (Acs et al., 2012; GERA, 2018; Freund, 2016).

\section{Restauranteurship}

Previous literature focused on restauranteurship is very limited. However, some previous works written have focused on restaurants and their exposure within the market. If entrepreneurship looks at the process of building and designing a new business concept, then restauranteurship looks at the process of building and designing a new restaurant. A restaurateur is defined as an operator or proprietor of a restaurant (Webster's, 2018). Current research envelopes restauranteurship into the domain of entrepreneurship, but in many ways the aspects of planning, designing and opening a restaurant can stand on its own. An Australian example of upscale restaurant performance looked at online restaurant review profiling and interviews with restaurant consultants from a mixed method approach (Hallak et al., 2018).

Harrington and Ottenbacher's (2013) analysis of Michelin starred restaurants in Europe used a qualitative approach to derive data from chefs of independent high-end restaurants and understand their product development process. Lane (2010) offered a model that examined high-end Michelin rated restaurants with an interdisciplinary model built from cultural economy theory, the sociology of culture and institutionalist theory to identify Michelin restaurants as a cultural industry. As with many SMEs, restaurants hold many of the same structural challenges, such as barriers to entry, price sensitivity, market saturation and many others (Assaf et al., 2011; Lee et al., 2015). What makes restaurants unique from other SMEs is the focus of the creation and sales of food products, not to mention the challenges associated with food production. Nonetheless, being a restaurateur is an exciting and risk-taking venture within SMEs. New York Times food writer Florence Frabricant (2008) once wrote that "restaurant openings can require Olympian levels of planning" just to get the doors open. Chefs and restaurateurs have to deal with health and safety inspections, culinary and sustainability awareness within their community and a near hyper-aggressive competition scale in today's restaurant market (Lee et al., 2015; Fabricant, 2008).

\section{Innovation in restaurants}

Restaurants are also seen as innovative SMEs. Previous research has seen that restaurant can reduce costs and improve sales through a variety of innovative details not limited to menu development, product differentiation and culinary creativity (Ottenbacher and Gnoth, 2005). These innovations can be examined from all levels of restaurant organizations SME and corporations alike. Most restaurant operations would be classified into the SME category, and therefore aspects of innovation for these restaurants would be likened to service (food and delivery), management and marketing. These among other aspects are needed to break into the market and differentiate themselves from the competition (Hjalager, 2010). Innovation and restauranteurship can be observed in the wide range of restaurant classifications: casual dining, quick service, fast casual and fine dining (Ottenbacher and Harrington, 2007a, b; Harrington and Ottenbacher, 2013). 
However, in most cases the restaurants with the highest performance tend to go to market first with new products, services and innovations (Jogaratnam et al., 1999). For this paper, the focus will be primarily on premium and upscale restaurants. Previous research has indicated that in the current global restaurant environment, upscale restaurants can be seen as the trendsetters and innovators. Their ability to create a unique character, feel and ambiance gives consumers the sense of having more value for their money spent than most casual or mid-scale restaurants (Sirieix et al., 2011; Lee et al., 2016). This environment becomes an innovative breeding ground, as the changes are constant for these restaurants to remain competitive within the market (Lee et al., 2016). These disruptions within the market have driven upscale restaurants to new heights within the industry (Hallak et al., 2018).

\section{Hong Kong's entrepreneurial ecosystem}

Hong Kong has become a start-up hub in the last decade (InvestHK, 2018; JETRO HK, 2018; Kim, 2017; GERA, 2018). It is also been called an "Innovation Driven Economy" from the 2016 GEM survey. This means that Hong Kong is one Asia's top locations for start-ups for a variety of different businesses, including restaurants. A 2016 survey done by InvestHK found that there are nearly 2,000 start-ups in Hong Kong with an estimated one (1) restaurant or café for every 600 local residents, it's per capita is larger than most cities around the world (Hannam, 2018). From the Hong Kong government and Global Entrepreneurship Monitor data, roughly 35 percent of Hong Kong's consumer service driven entrepreneurship focused on hospitality (GERA, 2018). Hong Kong is a place where these types of entrepreneurial models will thrive. Concerning this paper, it can be seen that Hong Kong presents itself as unique environment for both local and foreign restaurant start-ups and investors. Forbes magazine (Kim, 2017) listed for major components for Hong Kong's thriving system: talent, investment capital, infrastructure and support. In the last decade, Hong Kong has positioned itself maximize those components for investors to capitalize on. The Hong Kong government also allocated HK $\$ 2$ bn (US $\$ 254,789,890$ ) dollars to enhance innovation and provide support for start-ups. This has helped create more opportunity for restaurateurs as their initial startup. As Hong Kong now boasts more than 20 restaurants with Michelin stars and has several restaurants on the San Pellegrino Asia's Top 50 list, many restaurateurs are looking take a piece of the action (Baldwin, 2017; Hannam, 2018).

However, Hong Kong also has its challenges. Much like for any startup, there are bound to be challenges and barriers to entry for both local and foreign restaurateurs. It simply boils down to the largest costs for setting up the restaurant: cost of food, salaries and rent. For Hong Kong, rent is probably the most problematic as Hong Kong is known for having the most expensive rent in the world (Kim, 2017; Zhen, 2017; Li, 2015). Commercial and retail locations can range from HK $\$ 50$ to HK $\$ 120$ (US $\$ 6.37-U S \$ 15.30$ ) per square foot, and the size of the restaurant can vary from a take-away counter/kitchen that is 100 sq. ft. up to a 1,000 sq. $\mathrm{ft}$. restaurant (Li, 2015). Most rental agreements also stipulate that 2-3 months of rent be given up front, as a deposit that can double startup costs for a budding restaurateur in the city. Labor rules and guidelines are strictly enforced by the government while food costs (depending on the restaurant) can be subject to the rising costs of imports as Hong Kong has more than 90 percent of its food products imported from overseas (CSDHK, 2017). Even with these challenges, Hong Kong still manages to attract overseas restaurateurs to come and bring their business concepts (InvestHK, 2018).

\section{Community entrepreneurship and Hong Kong's Japanese restaurant market}

Japanese restauranteurship in Hong Kong, in comparison with others areas, is quite small. Yu's (2000) description of Hong Kong's entrepreneurship describes how Hong Kong's entrepreneurial economy provides a robust environment for various entry points into the market, but is more of an overview of the term entrepreneurship. As for the Japanese 
IHR

32,1

entrepreneurship in Hong Kong, there is not much focus academically on the restaurant industry; however, Kawahara and Speece's (1994) examination of the strategies Japanese supermarkets took to expand into Hong Kong is one of the closest pieces that looks at this particular and unique market. It is noted that for this paper, the focus is put on Japanese foreign restaurateurs.

Welter's (2011) definition of community entrepreneurship states that the aspect of entrepreneurship moves away from an individual and toward a collective. This could be in relation to local boundaries within the target location, governmental influence as well as the environment that the community resides in (Dupuis and de Bruin, 2003).

This paper puts forth the idea that as a whole, the Japanese restaurateurs of premium Japanese restaurants function in some aspect of community entrepreneurship or community restauranteurship. The legacy of Japanese restaurants in Hong Kong dates back to the turn of the twentieth century. There is a little official record but local culinary historians believe that the first Japanese restaurants were open in Japanese hotels or ryokans (Nakano, 2015; HKJRA, 2004). As Hong Kong was a major port and trade city at that time, Japanese entrepreneurs found that the sailors and traders need places to find their traditional cuisine. This is not unlike how the first Japanese exodus to the Netherlands became the foundations for Japanese cuisine's growth in Europe (Cwiertka, 2006).

While the beginning of the Japanese restaurant market starts there, the growth of these restaurants is very much tied to the expatriates from Japan and the growth of Japanese firms expanding into Hong Kong (Nakano, 2015; Yoshida, 2016). Japanese restaurants and restaurateurs have entered the Hong Kong market in phases. After the Ryokans were built in the pre-World War period, the next large influx of Japanese restaurant representation came from the supermarket sector. The supermarket retailers in Japan began to see opportunity amongst the international markets, Hong Kong being one of them this became the second phase (Kawahara and Speece, 1994; Nakano, 2015). In 1960, a Japanese supermarket Daimaru opened its doors in Causeway Bay on Hong Kong Island. This would later become a key turning point for the Japanese restaurant industry Hong Kong as Daimaru and the following supermarkets would set precedent for Japanese food in Hong Kong (Daimaru, 1967: Kawahara and Speece, 1994; Nakano, 2015). The third phase came about when the Hong Kong Japanese Restaurant Association (HKJRA) was assembled from the restaurant owners and chef/owners of Japanese restaurants in Hong Kong. This became a collective body of mostly Japanese and local Hong Kong restaurant owners promoting and raising awareness of Japanese cuisine in Hong Kong (Nakano, 2015; Baldwin and Hong Kong Polytechnic University, School of Hotel Tourism Management, 2016). These Japanese restaurateurs were among the people that had come to Hong Kong as businesspersons and saw an opportunity. Later, Hong Kong would see more large-scale companies like Ajisen and Beppu Ramen, Genki Sushi and Yoshinoya make their way into the restaurant markets (Yoshida, 2016; Nakano, 2015; Baldwin and Hong Kong Polytechnic University, School of Hotel Tourism Management, 2016). Given the role that the HKJRA plays within Hong Kong's restaurant market, it can be theorized that the organization functions within Welter's (2011) definition of community entrepreneurship.

\section{An overview of Hong Kong's Japanese restaurant market}

Table I below gives a chronological list of Japanese restaurant corporations that expanded into Hong Kong.

The restaurant model that seemed to be the most successful was large-scale buffet style Japanese restaurants were customers could sample a variety of Japanese food products (Nakano, 2015; Baldwin and Hong Kong Polytechnic University, School of Hotel Tourism Management, 2016). This created openings for more fast-casual style Japanese 
restaurants like Watami and Uoyaicho to come to Hong Kong and take part in the growth and popularity of Japanese cuisine (InvestHK, 2017b). The value-for-money model and design were immediately popular with local Hong Kong people and have become mainstays within the local Hong Kong dining community (Nakano, 2015; Lee, 2009).

Figure 1 shows the increase of Japanese restaurants in Hong Kong from 2001 to 2017 indicating a steady increase during this time and the most significant market share of restaurants in the market, behind Chinese cuisine of course. In 2017, Hong Kong's restaurant establishment statistics had over 16,000 restaurant establishments, of which 1,380 were Japanese restaurants roughly 10 percent of the market share. For reference, the combined total of Korean, Thai, Vietnamese, French and Italian restaurants was 1,070 or less than 1 percent of the total market share (HSIC, 2018; InvestHK, 2017a).

Table II shows the ranking of market share for corporate Japanese restaurants. The Japanese restaurant market is extremely competitive but is also highly fragmented in the low to mid-scale market (InvestHK, 2012). Average check per customer parameters within this particular market are in the lower range (HK\$50-HK\$100/US\$6.37-US\$12.74US), particularly for the restaurants listed within the table. For the large-scale market establishments, such as Ajisen Ramen, Genki Sushi and Itacho are on the forefront of the this market while the mid to premium market includes restaurants such as Nobu, Inagiku, Nadaman and Sushi Hiro (InvestHK, 2012; Nakano, 2015). The average check per cost for this market starts at roughly HK\$500 (US\$63.71) and goes up from there. It is important to note that the information provided by the government here does not include the nano-market of the high-end premium and Michelin rated Japanese restaurants in Hong Kong.

\begin{tabular}{lr}
\hline Nadaman & 1981 \\
Aeon & 1985 \\
Yoshinoya & 1991 \\
Watami & 2001 \\
Nihon-Ramen Yokocho & 2003 \\
Warawara, Tsukiji-Gindako, Japan Dining World & 2004 \\
Nobu, Mos Burger & 2005 \\
Coco Ichibanya, BUTAO, Gyu- kaku & 2010 \\
Marugame Seimen, Tomizawa & 2013 \\
Hyakunousha International & 2014 \\
Yonekura & 2015
\end{tabular}

Source: Complied from InvestHK (2017a) and JETRO Hong Kong (2013)

1981

1985

1991

2003

2004

2005

2010

2013

2015
Japanese restaurant market

Table I.

Major Japanese restaurant corporations that expanded into Hong Kong (by year)

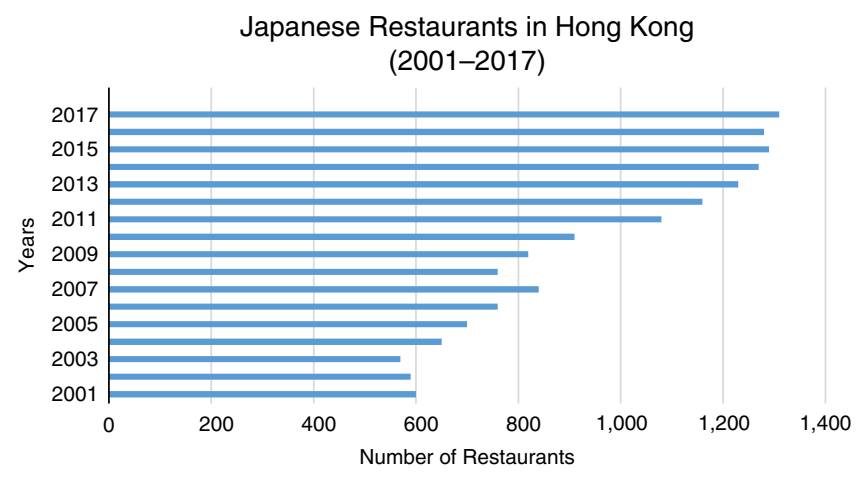

Figure 1.

Major Japanese

Restaurant

Corporations that

expanded into

Hong Kong 
IHR

32,1

14

One of the major objectives of this paper is to help establish similar guidelines and parameters for this market.

\section{The Michelin guide and Hong Kong's Japanese restaurants}

Previous described as a nano-market, Hong Kong boasts over 40 restaurants of various cuisines styles with stars or Bib Gourmande ratings. Of those restaurants, only six of them are Japanese restaurants. This has created a unique restaurant demographic for Hong Kong's restaurant scene overall but also for the Japanese restaurant community. In addition, for most of these restaurants, they are transplants or expansions of previous concepts within Japan that have blossomed in Hong Kong (Baldwin and Hong Kong Polytechnic University, School of Hotel Tourism Management, 2016). Since 2006, Hong Kong has had high-end premium Michelin rated Japanese restaurants awarded stars within the guide. For restaurants, the way to measure the experience of cuisine consumed by a restaurant's clientele is to use a measurement of culinary excellence and quality (Chi et al., 2013). Concerning the ranking of restaurants, indicating culinary excellence and reliability the Michelin Guide is one of world's top resources (Cotter and Snyder, 1998; Lane, 2010; Baldwin, 2017). The Michelin Guide has been used since the early 1900s in Europe but only within the last decade has the Guide been used in Asia (Michelin Guide, 2018). The rating system is as follows.

$\mathrm{R}$ - Good for the price:

(1) Star - "Very Good."

(2) Star - "Worth a Detour."

(3) Star - "Worth a Special Journey" Bib Gourmande- Honorable Mention.

The rating system carefully looks at overall restaurant ambiance, cuisine and culinary quality in creating a dining experience (Michelin Guide, 2018).

\section{Methodology}

The current range of academic restauranteurship research methodologies is in short supply, and as such, a focus on restauranteurship in Hong Kong is relatively small as well. This exploratory research intends to help expand the current methodological approaches to the topic within the discipline. One of the closest methodologies that examine the Japanese restaurant phenomenon comes Baldwin (2017) focuses on Japaneseness as a measurement of culinary authenticity examining Hong Kong's Michelin rated restaurants. Here, the qualitative approach using semi-structured interviews with the chefs of two sets of premium Japanese restaurants from Japan that expanded in Hong Kong, Sushi Iwa and Sushi Yoshitake. As this paper focuses on the premium and high-end market of Japanese chefs and restaurateurs in Hong Kong, the researcher combined the approaches of Kawahara \& Speece and Baldwin to pursue a qualitative methodology using semi-structured interviews. To facilitate the research

Table II.

Percentage of market share of top five Japanese restaurants in Hong Kong (2010-2012)

\begin{tabular}{lccccrl}
\hline Brand & Rank & $2010(\%)$ & $2011(\%)$ & $2012(\%)$ & Outlets & Revenue per outlet \\
\hline Genki Sushi & 1 & 4.8 & 6.4 & 6.4 & 45 & $\mathrm{HK} \$ 11.8 \mathrm{M}$ \\
Itacho Sushi & 2 & 4.2 & 4.8 & 5.2 & 31 & $\mathrm{HK} \$ 13.8 \mathrm{M}$ \\
Ajisen & 3 & 3.3 & 3.1 & 2.9 & 29 & $\mathrm{HK} \$ 8.3 \mathrm{M}$ \\
Watami & 4 & 1.6 & 2.0 & 2.1 & 17 & $\mathrm{HK} \$ 10.4 \mathrm{M}$ \\
Itamae Sushi & 5 & 0.9 & 0.9 & 1.0 & 8 & $\mathrm{HK} \$ 10.5 \mathrm{M}$ \\
Others & & 85.2 & 82.8 & 82.4 & 1,030 & $\mathrm{HK} \$ 5.8 \mathrm{M}$
\end{tabular}

Note: Taken from official statistics, company sources, trade interviews, trade press and Euromonitor International estimates 
design, the semi-structured interviews were divided into two parts: sole owner and shareholders/partners. This was done to provide insight into both the Japanese restaurant market and suppliers of Japanese food products. In this particular case, the Japanese food suppliers are Japanese entrepreneurs who do not own a restaurant but are still affiliated with the Japanese restaurant industry in Hong Kong.

The reason this was done because of the nature of foreign investment entrepreneurship in Hong Kong. For most of the respondents, they were not Hong Kong full permanent residents at the time of the interview. Those who were Hong Kong residents had become citizens by staying in Hong Kong for seven years or longer. This meant that in order to bring their business/concept to Hong Kong they had to meet certain criteria for opening their startup, namely liquid cash and meeting the various visa requirements (InvestHK, 2018). That being said most of the respondents, when asked about how they were able to startup their businesses went with either the Investment Visa, Entrepreneur Visa or standard working visa. Each visa has different requirements and criteria for applicants to meet when applying but yield the same result. Within this study, more than half of the respondents started their businesses in Hong Kong with an Investment Visa. While the Hong Kong Immigration does not state the financial amount needed but several respondents indicated that they presented initial startup financials and bank statements between HK $\$ 500,000$ and HK $\$ 1,000,000$ (US $\$ 63,726-U S \$ 127,452$ ) or more depending on the business model. Those that could not apply for the Investment Visa had to find a local Hong Kong born partner to co-operate the business for startup. A preliminary interview with representatives from InvestHK reported that this is a common practice for foreign SME business owners trying to break into the Hong Kong market (Chiang, 2018).

For this research, the interview process had to be divided into two stages. The first was to speak with long standing members of Hong Kong's Japanese restaurant community. Interviews were conducted with the president of the HKJRA, the Japanese External Trade Organization Hong Kong Deputy Director, and a tenured Professor of Japanese Studies at Hong Kong University. These individuals are seen leadership and historical reference points for the Japanese restaurant community. Each of them has been in Hong Kong for more than 25 years and has watched the latter part of the evolution and acceptance of Japanese food in Hong Kong. Historical data from the first stage of the interviews were used to help create the questions that would be used for the second stage. As such, with the recommendation from the president of the HKJRA, two of Hong Kong's premium Japanese bars were added to the list. While they are not Michelin listed, they are regards as two of the most successful entrepreneurial ventures representing Japanese craft cocktail making and sake in Hong Kong. After the interviews were completed with both organizations, the interviews with the chefs and restaurateurs began. In all, ten individuals were interviewed overall. All of the interviews were in person at the interviewee's office or restaurant. The interviews were voice recorded and interviewee responses were recorded via tablet and transcribed for analysis. It is also noted that there was no need for translation as all of the interviewees had good command of English.

The common thread amongst the restaurateurs was that they were either the sole proprietor or a partner who was financially invested within the company. To respect the privacy of the interviews, questions about exact monetary amounts, number of shares and equity or anything regarding to holdings were not asked. The premise of this research was to only examine their responses within the criteria of the research objectives. The research objectives were as follows:

$R Q 1$. What factors led Japanese restaurateurs to open their business in Hong Kong?

$R Q 2$. What are the barriers to entry for Japanese restaurateurs within Hong Kong's restaurant market? 
IHR

32,1

With those objectives, the interview questions were broken down into groupings: HKJRA, JETRO and HKU Question Groupings:

- role in the Japanese Restaurant Community;

- general perception of Japanese food in Hong Kong;

- infrastructure and support for Michelin rated Japanese Restaurants; and

- identity and integrity of Japanese Cuisine - flavors, taste and presentation.

Restaurateur interview question groupings:

- issues and challenges starting up in Hong Kong;

- startup support (financial and government);

- motivation and inspiration; and

- restaurant market and demographics.

Upon completion of the interviews, a contextual analysis was done to discover if any themes related to the response would be revealed. A contextual analysis of the respondents yielded the following themes:

- barriers to entry-location issues and monthly rental fees;

- Hong Kong as a "secondary" Japanese restaurant market;

- issues and concerns for the future of Japanese restaurants in Hong Kong; and

- factors for success - timing, community and government support.

\section{Limitations}

As the Michelin and premium market of Japanese restaurants is so small, this research can only represent a certain part of the market. Future research could examine other Japanese restaurateurs outside of this market that could be examined to gain a wider perspective of the entrepreneurial strategies they used to start up their business in Hong Kong. This study also only focused on non-local/non-permanent Japanese residents of Hong Kong rather than the whole market representation of Japanese restaurateurs in Hong Kong.

\section{Findings}

Table III shows the demographic information of the second stage of interviewees. The interviewees were all Japanese, predominately male, and all above the age of 30 years old at the time of the interview. Their education background varied but only three of them went to University for Baccalaureate degrees while the others (mostly chefs) completed culinary training apprenticeships in Japan. Four of the chefs had completed 3-5 years of culinary training with Michelin starred chefs in Japan prior to coming to Hong Kong. Concerning the majority of ownership for the interviewees, only two were sole proprietors.

What this means is that of the ten interviewed, only two came to Hong Kong with enough foreign investment capital to start their companies with no local partner, Nishiki and Sake Bar GINN. The other eight either bought into their company upon arrival or after working a few years bought a financial stake of the company.

Respondents who were partners in the restaurant stated that this happened to them in different ways. Three of the chefs cited that they initially came to Hong Kong to help expand the existing restaurant brand outside of Japan (Sushi Yoshitake, Ryu Gin and Sushi Masa). It is worth noting that the chef from Sushi Masa was originally working in Hokkaido but moved to Singapore to open a restaurant, which received one star. He was then approached 
Respondent demographics

Japanese

Gender

Male

Female

Age

18-25

26-33

34-40

41-50

51-60

50 or older

Education

University

Apprenticeship

to be a full partner of Sushi Masa in Hong Kong. From the data collected and the preliminary interviews, this seems to be the most common ways that SME restaurateurs move or expand their business from Japan into Hong Kong. The second way that the interviewees became partners was by leaving their mother company to start their own restaurant. The respondents from Ryu Gin, The Butler, Sushi Masa, Den by Saotome (formally Wagyu Kaiseki Den) organized proposals to local Hong Kong partners to start up their own restaurants. The result was an agreed upon stake in the business with creative control over the menu, hiring and day-to-day operations.

Table IV lists the restaurants that are in the Michelin and premium high-end nano-market of Hong Kong's Japanese restaurant community. The literature review indicated that within the Japanese restaurant market in Hong Kong, the greater majority of Japanese restaurants are large-scale chain restaurants with low average checks per guest. The mid-scale market tends to go up to about $\mathrm{HK} \$ 500$, which seems to a cutoff point that separates socio-economic classes. For this research, the premium market of Japanese restaurants is priced on the extreme high end (HK\$3,000/U\$\$382.29), as seen below. All the restaurants listed below are Michelin listed except for two.

\begin{tabular}{lllllll}
\hline Restaurant name & $\begin{array}{l}\text { Michelin } \\
\text { listing }\end{array}$ & $\begin{array}{l}\text { Type of } \\
\text { restaurant }\end{array}$ & $\begin{array}{l}\text { Avg. check } \\
(\mathrm{HKD})\end{array}$ & Ownership & Years & Signature \\
\hline Nishiki & $\mathrm{B} / \mathrm{G}$ & Yakitori & $\$ 500$ & Sole & 20 & Grilled Skewers \\
Shugetsu & $\mathrm{B} / \mathrm{G}$ & Ramen & $\$ 150+$ & Partner & 5 & Shugetsu Ramen \\
Sushi Ginza Iwa & $*$ & Sushi & $\$ 3,000^{*}$ & Partner & 4 & Omakase Sushi \\
Sushi Shikon & $* * *$ & Sushi & $\$ 3,800^{*}$ & Partner & 3 & Steamed Abalone \\
Ryu Gin (HK) & $* *$ & Kaiseki & $\$ 3,000^{*}$ & Partner & 3 & Fruit Ice Cream \\
Den by Saotome & $* *$ & Kaiseki & $\$ 3,000^{*}$ & Partner & 10 & Wagyu \\
Ta Vie & $*$ & French & $\$ 3,000^{*}$ & Partner & 3 & Botan Jelly \\
Sushi Masa** & $*$ & Sushi & $\$ 3,500^{*}$ & Partner & 1 & Omakase Sushi \\
The Butler & N/A & Bar & $\$ 500+$ & Partner & 5 & Craft Cocktails \\
Sake Bar GINN & N/A & Bar & $\$ 500+$ & Sole & 6 & Sake
\end{tabular}

Notes: $\mathrm{B} / \mathrm{G}$ indicates Bib Gourmande. *Indicates an Omakase dinner offering per person

Table IV. Premium and Michelin Rated Japanese Restaurants in Hong Kong 
IHR

32,1

The preliminary interviews with the HKJRA, JETRO and the professor from Hong Kong University yielded an interesting perspective on Japanese cuisine and restaurants in Hong Kong. Each of the respondents agree that the evolution of Japanese food in Hong Kong has played a significant role in both the increase of Japanese restaurants as well the high-end premium Japanese restaurant market. From Yu's (2000) description of the strategies of Hong Kong's entrepreneurs and the business environment of Hong Kong along with the country's free trade port system, makes Hong Kong is the one of the best places for Japanese cuisine to thrive. All these elements have created a rich entrepreneurial environment for local and foreign investment.

\section{Barriers to entry}

For the theme of barriers to entry, only the two sole proprietors could give a perspective of coming into Hong Kong and starting from zero as an SME. While the others, once they secured finances and partnership they were able to analyze their barriers to entry. The two repeating issues that came up were location and rental fees. While Hong Kong promotes itself globally as an entrepreneurial hub for starts-up, possibly the most expensive aspect would be rent and location of venue. For this research, all the restaurants were operating in West Kowloon, Tsim Sha Tsui area or across various districts on Hong Kong Island. All these areas are densely populated with international tourist traffic, which has a direct impact on rental prices. This impact makes it very troublesome for someone with limited capital to start up any business, let alone a restaurant. One respondent commented:

I was in Hong Kong for about 3 months before I found the space that I liked for my bar. In 2011, my first rental lease was for about $\mathrm{HKD} \$ 40,000$ ( $\$ 5,000 \mathrm{USD}$ ) per month. 7 years later my property owner has more than doubled my rent. In Hong Kong it is perfectly legal for landlords to do this for commercial businesses.

Several respondents had similar issues concerning finding their location. As part of the rental agreement, the property owner has the right to review the income statements to gauge performance. It was widely commented that as the restaurant does better, the rental fees would increase. This was exactly the case when speaking with the chef partner of Den by Saotome. The restaurant was previously called Wagyu Kaisen Den and was located in the Sheung Wan District of Hong Kong Island. The Michelin starred restaurant was doing very well and receiving international accolades when the property owner doubled the rent for extending the contract. This forced the restaurant to close temporarily and relocate to a less expensive venue in the Wan Chai district of Hong Kong. As upsetting as this was the move created the opportunity for the chef to become a partner within the new restaurant. Although within the interview the chef did mention that if the new landlord doubled the rent they would have to repeat the process as they did before or close down permanently.

While all the respondents shared their concerns with rental fees and locations issues, two restaurants had slightly different situations befall them. Nishiki, located in the Regal Kowloon Hotel in East Tsim Sha Tsui, is the oldest standing Michelin listed Japanese restaurant in Hong Kong. Holding a Bib Gourmande rating and having been in business for over 20 years, the owner of Nishiki mentioned that he had never had an issue with the space as his agreement with the hotel benefited both parties. In the 1990s, few hotels had Japanese restaurants save Nishiki in the Regal Kowloon. The hotel back then served as point of stay for Japanese business people working in Hong Kong. Being one of the only Japanese restaurants in the area at that time created a niche for the both restaurant and the hotel. It was best for both parties to serve each other to preserve their clientele. Decades later, this formula is still working and Nishiki is still one of the most popular Japanese restaurants in Hong Kong. 
A similar situation happened to Ta Vie, a Japanese French fusion restaurant located in the Pottinger Hotel in the Central District of Hong Kong. Formerly the executive chef of the two-star Michelin rated Ryu Gin Hong Kong; the same investor who worked with Chef Yamamoto of Ryu Gin Tokyo to bring the concept to Hong Kong approached the chef from Ta Vie. The investor had a previous restaurant concept in the Pottinger that failed and proposed to the chef to collaborate and start his own restaurant in the hotel's space. This freed up the chef to create his own French inspired Japanese cuisine dishes, earning him two Michelin stars in the process.

Because the previous concept was still under the lease with the investor's company, there was a little to no cost to move into the space. The chef put up a percentage of his own funds for shares within the restaurant and began to build the concept. The restaurant is now in its third year of operation and was acknowledged by San Pellegrino's Asia's Top 50 restaurants.

Barriers to entry are a common hurdle for a business, but the economic environment of Hong Kong makes it unique for foreign investment coming into the country. Most potential entrepreneurs and SME owners will not know the trials and tribulations they will encounter until they are in Hong Kong and ready to start their business.

\section{Hong Kong as a secondary Japanese cuisine market}

With Hong Kong being the chief importer of Japanese food products for more than a decade, the growing acceptance of Japanese cuisine from the local population and a global emergence of Japanese culinary culture the respondents felt it natural to open a restaurant in Hong Kong. With nearly three decades of groundwork laid down by previous generations, new restaurateurs could map out a framework for success with their individual restaurant concepts. No respondent said that it was easy, but they did mention two key factors that played a role in starting up their SME; Hong Kong as a free trade port and Japanese government support. As most of the Japanese restaurants were serving typical Japanese dishes like ramen, fried pork cutlet, sushi and many others, theses restaurateurs saw opportunity to focus on other styles that were not as readily produced in Hong Kong. For most of the Michelin rated restaurants, bringing more formal Kaiseki to the locals was the next step for Japanese cuisine. The current president of HKJRA commented:

Our generation had worked hard to establish Japanese food amongst the Hong Kong people. So much so, that Japanese food had become a daily staple in the lives of Hong Kong people. This took time to build, but the current wave of restaurant owners has benefitted from what we have done.

Hong Kong was ripe for the next phase of Japanese restaurants as Sushi Yoshitake, Ryu Gin and Sushi Iwa brought their restaurant brands to Hong Kong. Although there were several premium Japanese restaurants with Kaiseki cuisine, things began to shift when two of the biggest names in Japanese cuisine came to Hong Kong. Several respondents mentioned that they saw the success of these brands and felt that the market was ready for a different and more premium Japanese food product. The owner of Sake Bar GINN commented:

I previously looked at Singapore and Shanghai before settling on Hong Kong as the place to open my bar. At that time [2011], there were no restaurants specializing in premium sake and food pairing. There were several sake bars, but they were being marketed to a younger crowd with limited knowledge of Japanese sake. I created my niche based on what I saw in the market.

The owner of The Butler, a Tokyo-themed premium cocktail bar, said the same. While there was exponential growth with Japanese restaurants, izakayas and cocktail bars were not well represented. This presented more opportunities for skilled Japanese bartenders to make their mark within the market. Hong Kong's love affair with Japanese cuisine allowed the 

cuisine even further in Hong Kong:

Outside of hotels and high-end restaurants, there were few places to experience a true Japanese craft cocktail. By taking this approach to making drinks, my customers have developed an appreciation for the cocktails we produce. Our drinks sell for a premium, but the customer gets exactly what they pay for.

From Baldwin's (2017) analysis of the Sushi Yoshitake and Sushi Iwa brands, the term Japaneseness was used to describe what steps Japanese chefs take to ensure their food is as Japanese as possible. While it is common to see some alterations made to food outside of the native country it is from, Hong Kong as a market does not have the same restrictions (Baldwin and Hong Kong Polytechnic University, School of Hotel Tourism Management, 2016). Concerning Japanese cuisine, chefs and restaurateurs will have an easier time starting up a restaurant in Hong Kong than most places because of the level of acceptance locals have for Japanese food.

\section{Issues and concerns}

The interviews yielded several issues that are worth mentioning concerning Japanese restaurants in Hong Kong. Issues that arose from the interviews were centered on from the backlash from Fukushima tragedy, and value of the Japanese yen and the current pricing structure of Japanese restaurants in Hong Kong.

Both are interesting points about how Japanese food is perceived from a management standpoint. The respondent commented:

Within 5 years, Hong Kong's economy and rental prices are projected to see a $20-30 \%$ increase which will force some restaurants to close. We have also noticed a change overall in the target market audience and it is getting smaller. This and the fact that labor is getting more expensive makes it more difficult to employee new staff.

One respondent commented about the Fukushima incident saying that Japan's food trade is still trying to recover from the incident. The government has been putting a lot effort into helping give the public information about the inspections proving that Japanese food is still safe for consumption. One respondent commented, "If we can help the public understand that the import and export process for Japan and other countries is quite thorough and rigorous this will help our customers know that our food is safe."

A respondent also commented:

The Japanese government needs to help more with the issue and help with educating the public about how strenuous the export laws of Japan and the import laws of Hong Kong are after Fukushima the media to help show the food is safe. We as restaurant owners do our best to help the customer understand we are serving the safest food but our word only goes so far.

\section{Success factors timing}

For the success factor timing, nearly all of the responded indicated that after doing their market research and due diligence for their startup in Hong Kong the timing could not have been better. They commented that once they connected with the previous HKJRA members and other Japanese restaurant owners who informed them of Hong Kong's positive history with Japanese food they felt more comfortable entering the market. With Hong Kong being the number one importer of Japanese products, it is safe to say that Japanese food is very popular in Hong Kong and the local palate enjoys the flavor profile. The previous groundwork laid out by the entrepreneurs who brought teppanyaki, grilled eel and later sushi had set the stage for the more modern and Nouvelle inspired Japanese cuisine the likes of Ryu-Gin and Den by Saotome. Even with the scope of the bar and beverage sector for 
Japanese restaurants, the local Hong Kong acceptance gave way to the Japanese style of premium cocktail making, mixology and sake. These new bars and restaurants have been able to provide Hong Kong with more Japanese gastronomic delights.

\section{Community support}

Japanese cuisine and its restaurateurs have been able to enjoy a significant amount of support from different organizations as well as the local residents of Hong Kong. The Japanese government through JETRO and JFOODO (Japanese Food Abroad) have put decades of investment into the market thus making it ripe for entrepreneurial activity. Both the Hong Kong and Japanese governments have worked together in partnership to help promote Japanese food in Hong Kong as well. With Hong Kong's most recent entrepreneurship development for foreign invest, the stage has been well set with support for these restaurateurs. The collective community of the HKJRA, Japanese Bartender's Association and large corporations like Kikkoman and Suntory, it is evident that there is a sense of community entrepreneurship amongst the Japanese restaurateurs in the premium market segment. So long as Hong Kong remains a chief importer of Japanese products that relationship and community is set to remain strong in the years to come.

\section{Implications and future research}

While Hong Kong has been groomed for Japanese restaurateurs, there are some concerns that all entrepreneurs should be mindful of when bringing their concept to market. First of those concerns are the immigration restrictions and business licensing concerns. As the respondents indicated a starting point of roughly $\mathrm{HK} \$ 500 \mathrm{~K}$ in liquid cash for certain visas, ensuring that the seed capital amount more than enough for the business. There is also the personal finances to consider as well, foreign investors must prove that they hold enough funds in reserve to cover their personal living cost while setting up and implementing the business. Concerning when the restaurateur arrives in Hong Kong, it would be imperative to make contact with InvestHK, whose purpose is to assist with the transition into the local market by providing consulting services. On the side of community, depending on the region of the world the restaurateur is coming from, there may already be a contact or networking base. Associations like the HKJRA, Spanish Chefs Association, Disciples of Escoffier and the Hong Kong Chefs Association have strong reputations and are very willing to assist new restaurateurs in the area. For continuing research, with Hong Kong being Asia's new startup hub it presents an interesting environment for start up, entrepreneurship and restauranteurship focused research. To gain a better perspective of the overall restauranteurship model, studies could be done of the other styles of cuisine found in Hong Kong and the chefs and restaurateurs behind them.

\section{Conclusion}

Despite some negative aspects of the potential future of Japanese food in Hong Kong, there is room for Japanese food to continue to grow for the near future. Japanese cuisine has the strongest reputation outside of Chinese cuisine in Hong Kong. It is very influential and with the cuisine's strong and rich history in Hong Kong, it has become positioned to be a cuisine on the forefront of innovation and quality. As Japanese cuisine is seen to remain popular, there will be more opportunity for Japanese restaurateurs and SMEs to come to Hong Kong. The challenges discussed will most likely still exist but much like the work done by those in the past, this current generation is paving the way of opportunity for the future. 
IHR

32,1

\section{References}

Acs, Z., Brooksbank, D., O'Gorman, P.D. and Terjesen, S. (2012), “The knowledge spillover theory of entrepreneurship: an application to foreign direct investment", International Journal of Entrepreneurship and Small Business, Vol. 15 No. 2, pp. 237-261.

Assaf, A., Deery, M. and Jago, L. (2011), "Evaluating the performance and scale characteristics of the Australian restaurant industry", Journal of Hospitality \& Tourism Research, Vol. 35 No. 4, pp. 419-436.

Baldwin, W. (2017), “'Japaneseness' as a measurement of culinary authenticity in Hong Kong's Michelin rated Japanese restaurants", Journal of Tourism, Hospitality \& Culinary Arts, Vol. 9 No. 1, pp. 27-32.

Baldwin, W., Hong Kong Polytechnic University, School of Hotel Tourism Management (2016), The Transference of Cuisine and Michelin Rated Restaurants: A Chef's Perspective of Japanese Cuisine in Hong Kong, School of Hotel and Tourism Management, The Hong Kong Polytechnic University, Hong Kong.

Baumol, W.J. (1990), "Entrepreneurship: productive, unproductive and destructive”, Journal of Political Economy, Vol. 98 No. 3, pp. 893-921.

Brush, C., Duhaime, I.M., Gartner, W.B., Stewart, A., Katz, J.A., Hitt, M.A., Alvarez, S.A., Meyer, G.D. and Venkataraman, S. (2003), "Doctoral education in the field of entrepreneurship", Journal of Management, Vol. 29, pp. 309-331.

Busenitz, L.W., West, G.P. III, Shepherd, D., Nelson, T., Chandler, G.N. and Zacharakis, A. (2003), "Entrepreneurship research in emergence: past trends and future directions", Journal of Management, Vol. 29, pp. 285-308.

Cantillion, R. (1755), Essay on the Nature of Trade in General (translated by Higss H. 2913), Oxford University Press, Oxford.

Chen, A. and Chon, K. (2016), "Transferability of Asian paradigm in hospitality management to non-Asian countries", Tourism and Hospitality Management, Vol. 12, pp. 143-157.

Cheung, S. and Zou, X. (2013), "Hong Kong (China). Leisure and Cultural Services Dept., \& Chinese University of Hong Kong. Dept. of Anthropology", International Conference on Foodways and Heritage: A Perspective of Safeguarding the Intangible Cultural Heritage Hong Kong Heritage Museum, Department of Anthropology, the Chinese University of Hong Kong, Hong Kong.

Chi, C.G., Chua, B.L., Othman, M. and Karim, S.A. (2013), "Investigating the structural relationships between food image, food satisfaction, culinary quality, and behavioral intentions: the case of Malaysia”, International Journal of Hospitality \& Tourism Administration, Vol. 14 No. 2, pp. 99-120.

Chiang, J. (2018), “Associate director-general of investHK- personal communication May 2018”.

Cotter, M. and Snyder, W. (1998), "How guide books affect restaurant behavior”, Journal of Restaurant \& Foodservice Marketing, Vol. 3 No. 1, pp. 69-75.

CSDHK (2017), "Hong Kong merchandise trade statistics imports", Census and Statistics Department Hong Kong Special Administrative Region, Hong Kong.

Cwiertka, K.J. (2006), Modern Japanese Cuisine: Food, Power and National Identity, London: Reaktion Books, London.

Dupuis, A. and de Bruin, A. (2003), "Community entrepreneurship", in Dupuis, A. and de Bruin, A. (Eds), Entrepreneurship: New Perspectives in a Global Age, Ashgate, Aldershot, pp. 169-184.

Eckhardt, J. and Shane, S. (2003), "Opportunities and entrepreneurship”, Journal of Management, Vol. 29, pp. 33-349.

Fabricant, F. (2008), "Even Chefs have to wait for a table", New York Times Dining in, Dining Out, (1923-Current File) Historical Newspapers: The New York Times Index.

Freund, S. (2016), "Is Hong Kong a sustainable location for entrepreneurs and startups?", Forbes, available at: www.forbes.com/sites/shlomofreund/2016/06/20/is-hong-kong-a-sustainablelocation-for-entrepreneurs-and-startups/\#6a3acd5a4bf4 (accessed September 1, 2018).

Gartner, W.B. (1995), “Aspects of organizational emergence”, in Bull, I., Thomas, H. and Willard, G. (Eds), Entrepreneurship: Perspectives on Theory Building, Pergamon, Oxford, pp. 67-86. 
GERA (2018), “General entrepreneurship monitor global report 2017/2018”, Global Entrepreneurship Research Association, Hong Kong.

Granovetter, M. (1985), "Economic action and social structure: the problem of embeddedness", American Journal of Sociology, Vol. 91, pp. 481-510.

Hallak, R., Assaker, G., O'Connor, P. and Lee, C. (2018), "Firm performance in the upscale restaurant sector: the effects of resilience, creative self-efficacy, innovation and industry experience", Journal of Retailing and Consumer Services, Vol. 40, pp. 229-240.

Hannam, K. (2018), Opening a Hong Kong Restaurant- Why Rent Isn't Your Biggest Worry-Here's What You Need to Know, South China Morning Post, Hong Kong.

Harrington, R. and Ottenbacher, M. (2013), "Managing the culinary innovation process: the case of new product development", Journal of Culinary Science \& Technology, Vol. 11 No. 1, pp. 4-18.

Hjalager, A. (2010), "A review of innovation research in tourism”, Tourism Management, Vol. 31 No. 1, p. $1 \mathrm{e} 12$.

Hong Kong Japanese Restaurant Association (HKJRA) (2004), “”, Hong Kong Japanese Restaurant Association 25th Anniversary Edition.

Hong Kong Tourism Board (2018), available at: www.discoverhongkong.com/eng/index.jsp

HSIC (2018), "Number of establishments, persons engaged and vacancies (other than those in civil service) analysed by subclass HSIC V2.0", Quarterly Survey of Employment Vacancies, Census and Statistics Department, Hong Kong Standard Industrial Classification, available at: www.censtatd.gov.hk/hkstat/sub/sp452.jsp?productCode=D5250008 (accessed August 18, 2018).

InvestHK (2012), "Hong Kong restaurant industry overview”, InvestHK, May, Hong Kong.

InvestHK (2017a), "Tourism and hospitality case studies”, InvestHK, January, Hong Kong.

InvestHK (2017b), "Industry case study: expand Japanese cuisine into a broader horizon - Watami", InvestHK, March, Hong Kong.

InvestHK (2018), Tourism and Hospitality Case Studies, available at: www.investhk.gov.hk/en/settinghong-kong.html (accessed August 18, 2018).

Jogaratnam, G., Tse, E. and Olsen, M. (1999), "An empirical analysis of entrepreneurship and performance in the restaurant industry", Journal of Hospitality and Tourism Research.

Katz, J. and Steyaert, C. (Eds) (2004), "Entrepreneurship in society: exploring and theorizing new forms and practices of entrepreneurship", Entrepreneurship and Regional Development, Vol. 16 No. 3, pp. 179-250.

Kawahara, Y. and Speece, M. (1994), "Strategies of Japanese Supermarkets in Hong Kong", International Journal of Retail \& Distribution Management, Vol. 22 No. 8, pp. 3-12.

Kim, J. (2017), "Hong Kong's startup ecosystem is thriving- but this is out it becomes a global hub", Forbes, available at: www.forbes.com/sites/kimjay/2017/05/19/hong-kongs-startup-ecosystem-isthriving-but-this-is-how-it-becomes-a-global-hub/\#795bad6cb52f (accessed September 1, 2018).

Lane, C. (2010), "The Michelin-starred restaurant sector as a cultural industry", Food, Culture \& Society, Vol. 13 No. 4, pp. 493-519.

Lee, C., Hallak, R. and Sardeshmukh, S. (2015), "Innovation, entrepreneurship and restaurant performance: a higher-order structural model”, Tourism Management, Vol. 53, pp. 215-228.

Lee, J. (2009), Asian Palate, Savoring Asian Cuisine and Wine, Asset Publishing and Research.

Lee, L., Lee, M. and Dewald, B. (2016), "Measuring the customers' perceptions of tangible service quality in the restaurant industry: an emphasis on the upscale dining segment", Journal of Foodservice Business Research, Vol. 19 No. 1, pp. 21-38.

Lee, S. and Peterson, S. (2000), "Culture, entrepreneurial orientation, and global competitiveness", Journal of World Business, Vol. 35, pp. 401-416.

Li, S. (2015), Hong Kong Rent Falls, Letting Overseas Restaurants and Small Eateries Fill The Void, South China Morning Post, Hong Kong.

Low, M. and MacMillan, I. (1988), "Entrepreneurship: past research and future challenges", Journal of Management, Vol. 14 No. 2, pp. 139-161. 
IHR

32,1

McDougall, P. and Oviatt, B. (1997), "International entrepreneurship literature in the 1990s and directions for future research", in Sexton, D.L. and Smilor, R.W. (Eds), Entrepreneurship 2000, Upstart Publishing, Chicago, IL, pp. 291-320.

Michelin Star Guide (2009-2018), available at: www.viamichelin.com/web/Restaurants

Nakano, Y. (2015), “Eating one's way to sophistication Japanese food, transnational flows and social mobility in Hong Kong", in Soyal, Y.N. (Ed.), Transnational Trajectories in East Asia: Nation, Citizenship, and Region, Routledge, Oxford and New York, NY, pp. 106-129.

Ottenbacher, M. and Gnoth, J. (2005), "How to develop successful hospitality innovation", Cornell Hotel and Restaurant Administration Quarterly, Vol. 46 No. 2, pp. 205-222.

Ottenbacher, M. and Harrington, R. (2007a), "The innovation development process of Michelin-starred chefs", International Journal of Contemporary Hospitality Management, Vol. 19 No. 6, pp. 444-460.

Ottenbacher, M. and Harrington, R. (2007b), "The culinary innovation process: a study of Michelin-starred chefs", Journal of Culinary Science \& Technology, Vol. 5 No. 4, pp. 10-35.

Polanyi, K. (1957), The Great Transformation: The Political and Economic Origin of Our Time, Boston, MA, Beacon Hill.

Rahman, K. and Rahman, S. (2012), "Entrepreneurship needs and achievement motivations of descendant Latin-Japanese entrepreneurs in Japan”, International Journal of Entrepreneurship, Vol. 16.

Shi, L. and Yonezawa, A. (2012), "Innovation and entrepreneurship: trials of Japanese universities", Globalisation, Societies and Education, Vol. 10 No. 3, pp. 367-385, doi: 10.1080/ 14767724.2012.710469.

Sirieix, L., Remaud, H., Lockshin, L., Thach, M. and Lease, T. (2011), "Determinants of restaurant's owners/managers selection of wines to be offered on the wine list", Journal of Retailing and Consumer Services, Vol. 18 No. 500, p. 508.

Stevenson, H. and Jarillo, J. (1990), "A paradigm of entrepreneurship research: entrepreneurial management", Strategic Management Journal, Vol. 11, pp. 17-27.

Wan, S. and Chon, K. (2010), “Asianess - an emerging concept in hospitality management”, Proceedings of the 8th APac Chrie Conference Phuket.

Webster's Dictionary (2018), "Definition of a restaurateur", available at: www.merriam-webster.com/ dictionary/restaurateur

Weber, M. (1984), "Die protestantische Ethik und der Geist des Kapitalismus" (originally published 1920 by Mohr (Paul Siebeck), Tübingen) in Winckelmann, J. (Ed.), Max Weber, Die protestantische: Ethik I. Eine Aufsatzsammlung, 7th ed., Gütersloher Verlagshaus Mohn, Gütersloh, pp. 27-317.

Welter, F. (2011), "Contextualizing entrepreneurship- conceptual challenges and ways forward", Entrepreneurship Theory and Practice, pp. 165-184.

Yoshida, H. (2016), "President, Hong Kong Japanese restaurant association personal communication", January 8.

Yu, F. (2000), "Hong Kong's entrepreneurship: behaviours and determinants", Entrepreneurship \& Regional Development, Vol. 12 No. 3, pp. 179-194, doi: 10.1080/089856200413455.

Zhen, S. (2017), Hong Kong Records Highest Rent Ever in the Second Quarter, South China Morning Post, Hong Kong.

\section{Further reading}

Acs, Z., Desai, S. and Hessels, J. (2008), "Entrepreneurship, economic development and institutions", Small Business Economics, Vol. 31 No. 3, pp. 219-234.

Al-Jaime, A. (2013), The Man Who Brought Sushi to America Tokyo Journal, Tokyo Journal International, Tokyo and Los Angeles, CA.

Anwar ul Haq, M., Usman, M., Hussain, N. and Anjum, Z. (2014), "Entrepreneurial activity in China and Pakistan: a GEM data evidence", Journal of Entrepreneurship in Emerging Economies, Vol. 6 No. 2, pp. 179-193. 
Beynon, M., Jones, P. and Pickernell, D. (2018), "Entrepreneurial climate and self- perceptions about entrepreneurship: a country comparsion using fsQCA with dual outcomes", Journal of Business Research, Vol. 89, pp. 418-428.

Cusumano, M. (2016), "Technology strategy and management: the puzzle of Japanese innovation and entrepreneurship", Viewpoints, Vol. 58 No. 10, pp. 18-20.

Cwietrka, K.J. (2006), "From ethnic to hip: circuits of Japanese cuisine in Europe", Food and Foodways, Vol. 13 No. 4, pp. 241-272.

Daisuke, S. (2016), "Executive chef Sushi Ginza Iwa”, Personal Communication, January 7, Hong Kong.

Davidsson, P. and Honig, B. (2003), "The role of social and human capital among nascent entrepreneurs", Journal of Business Venturing, Vol. 18 No. 3, pp. 301-331.

De Bruin, A. and Mataira, P. (2003), "Indigenous entrepreneurship", in Dupuis, A. and de Bruin, A. (Eds), Entrepreneurship: New Perspectives in A Global Age, Ashgate, Aldershot, pp. 169-184.

Frederking, N. (1997), "Social Skill and institutional theory", American Behavioral Scientist, Vol. 40 No. 4, pp. 397-405.

Fukuzawa, Y. (1934), The Autobiography of Fukuzawa Yukichi, Hokuseido, Tokyo.

Granovetter, M. (2005), “The impact of social structure on economic outcomes”, Journal of Economic Perspectives, Vol. 19 No. 1, pp. 33-50.

Gruenwald, R. (2013), "Entrepreneurship challenges in high-growth companies and consequences for SME Policy", Entrepreneurial Business and Economics Review, Vol. 1 No. 1, pp. 41-54.

Haugh, H. (2007), "Community-led social venture creation", Entrepreneurship Theory and Practice, Vol. 32 No. 2, pp. 161-182.

Johannisson, B. (1990), “Community entrepreneurship - cases and conceptualization”, Entrepreneurship and Regional Development, Vol. 14 No. 4, pp. 297-315.

Johannisson, B., Ramirez-Pasillas, M. and Karlsson, G. (2002), "The embeddedness of inter-firm networks", Entrepreneurship \& Regional Development, Vol. 14 No. 4, pp. 297-315.

Kakinuma, Y. (2016), "Executive Chef Sushi Shikon”, Personal Communication, March 1, Hong Kong. Milligan, L. (2006), "Japanese cuisine and Japanisation of Europe”, Kontur nr. 13.

Nakano, Y. (2017), "Professor, Japanese studies Hong Kong University personal communication", May 7.

Nao, C. (2016), "JETRO representative personal communication", January 12.

Simon, H. (1990), "Hidden champions: speerspitze der deutschen wirtschaft", Zeitschirft für Betriebswirtschaft (ZFB), Vol. 60 No. 9, pp. 875-890.

Simon, H. (2007), Hidden Champions des 21. Jahrhunderts, Campus Verlag, Frankfurt/New York, NY.

Simon, H. (2012), Hidden Champions Aufbuch nach Globalia, Campus Verlag, Frankfurt/New York, NY.

Soriano, D.R. and Montoro-Sanchez, M. (2011), "Introduction: the challenges of defining and studying contemporary entrepreneurship", Canadian Journal of Administrative Sciences, Vol. 28, pp. 297-201.

Stierand, M. and Lynch, P. (2008), "The art of creating culinary innovations", Tourism and Hospitality Research, Vol. 8, pp. 337-350.

Tanaka, H. (2016), "JETRO representative personal communication”, January 12.

Welter, F., Trettin, L. and Neumann, U. (2008), "Fostering entrepreneurship in distressed urban neighbourhoods", International Entrepreneurship and Management Journal, Vol. 4 No. 2, pp. 109-128.

Yeung, K. (2018), Hong Kong Tech Start-Up Economy Sparking Into Life after Slow Start, South China Morning Post, Hong Kong.

\section{Corresponding author}

Watson Baldwin can be contacted at: wbaldwin@vtc.edu.hk

For instructions on how to order reprints of this article, please visit our website:

www.emeraldgrouppublishing.com/licensing/reprints.htm

Or contact us for further details: permissions@emeraldinsight.com 